\title{
Residents Resilience towards Insecurity: An Analysis of Socioeconomic and Demographic Profile of Respondents in Maiduguri, Borno State, Nigeria
}

\author{
Hauwa Mai Butu ${ }^{1}$, Ahmad Hariza Bin Hashim², Nobaya Ahmad ${ }^{3}$ \\ ${ }^{1,2,3}$ Faculty of Human Ecology, Universiti Putra Malaysia, 43400 UPM Serdang, Selangor, Malaysia \\ ${ }^{I}$ Department of Estate Management \& Valuation, School of Environmental studies Ramat Polytechnic \\ Maiduguri, Borno State, Nigeria.
}

\begin{abstract}
The study describes the socioeconomic and demographic profile of Maiduguri residents on resilience towards insecurity, using convenient sampling technique, with a sample size of 383 . The descriptive statistics was to describe the socioeconomic and demographic profile of the respondents. The results revealed that, the majority of residents are within the age bracket of 18-35, married, Muslims, and those who has tertiary education account for $603 \%$ of the majority. The result also indicates that most residents of the area are civil servant and business owners with few engaging in farming.Most of the residents lived in rented houses as compare to an owner occupier. The majority of the residents reside in the area for 1-10 years, while a large proportion falls within low-income bracket of $\$ 10,000-\$ 30$, 000.The socioeconomic and demographic profile of the residents will provide relevant information on the actual condition of the residents and what the affected residents need most in terms of assistance that would improve their condition and relief them of the hardship been posed on them by the insurgency predicament.
\end{abstract}

Keywords: Socioeconomic, Demographic profile, Resilience, Insurgency, Maiduguri, Borno State.

\section{INTRODUCTION}

Previous studies on residents' resilience have shown that socioeconomic and demographic characteristics of the residence within a neighbourhood play a significant role in influencing their decision to remain or relocate during periods of insecurity or natural disaster. [1]describes resilience as the capacity of a person or organization to quickly plan and device positive adaptive actions to match the immediate situation with minimal stress. The concept resilience is the ability and capability of an individual to withstand external shocks or unrest and to recover from such distress [2]. While insecurity invokes numerous interpretations, which involved the state of doubt, the absence of peace, danger, hazard, and lack of protection. In trying to defined what insecurity is, [3] affirmed that insecurity is a state of fear or been nervous due to the absence of peace and safety.Therefore, the aim of this study is to describe the socioeconomic and demographic profile of the respondents.

\section{LITERATURE REVIEW}

[4] conducted a study on resilience of older and younger Israelis, and found that older Israelis are more resilient than younger ones, their long experience of wars and terror attacks has not decreased their resilience, and perhaps strengthened their effort. A study carried out in Australian by [5] found socio-demographic characteristics of residents living in a threatening area, revealed an importance impact on the place of residence.[6, 7, 8 and 9] linked the reasons of residents staying preference with the length of residence. In another vein, [10] examined how housing characteristics of a neighbourhood where renters have chosen to live could influence their current decisions whether to stay in the neighbourhood or relocate from it. In another development [11] carried out a study in a flood-prone area in the Philippines, their studies indicate that, resident's length of stay facilitates an individual's to establish economic endeavor precise for that place. For instance, an individual may not be born in place, but due to his or her length of stay in the area, has developed necessary networks and skills to practice a certain economically satisfying activity. As a result, the place gains meaning as a place where one can depend upon economically, and thus, relocating to another place to avoid any events would also mean foregoing established economic activities. A study carried out by [12] revealed that, demographics overall have a significant influence on the choice of location of house. The results further showed that, gender was statistically significant in explaining the choice of neighbourhood decisions. [13] on the other 
hand use gender and age to observe whether there are significant predictors of resilience and found out that, people 65 years of age or older were resilient more than people between 18 and 24 years of age.

\section{METHODOLOGY}

This section comprises of the methods and procedures that was adopted to generate data for the study as well as the method that is used to analyze the data. It consists of the research design, the study area, the targeted population, the required sample size, and procedure for data collection. The population of the study area is 540,016, and the target sample size for the study is 383 . Questionnaires were use as an instrument for data collection, and data were analyzed using frequency distribution. The quantitative study allows the generalization of the findings from the study sample to a large population [14]. The survey design is the description of how the research was conducted to address the objective of the study

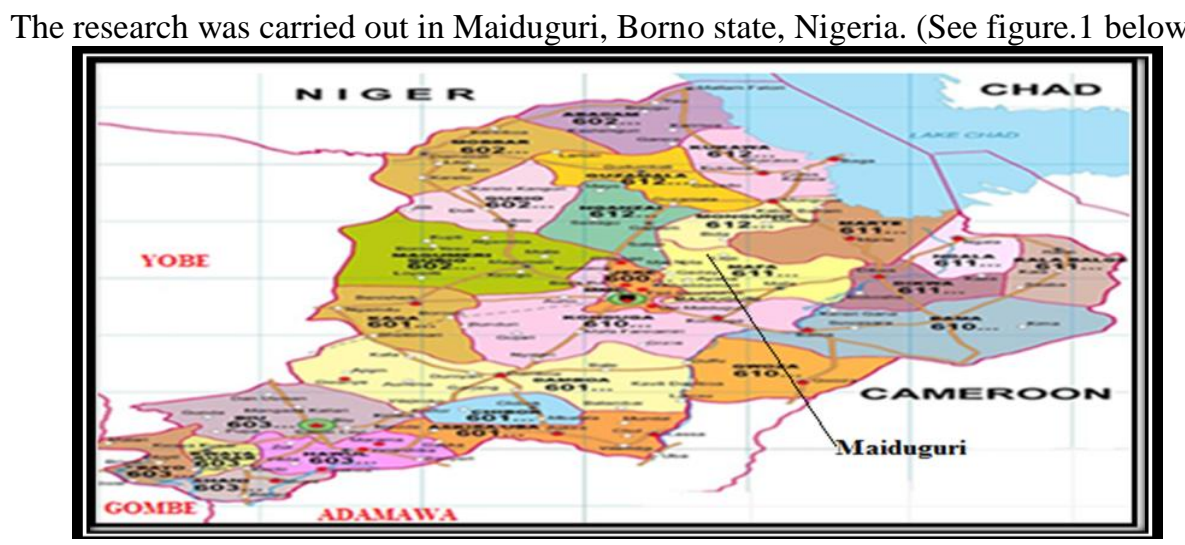

Figure. 1 Map of Borno showing Maiduguri

The total population of Maiduguri is 540,016, spread across 4 districts. The target population of this study comprises of residents who remain in their neighbourhood in the four major districts of Gwange, Bolori, Yerwa and Mai Sandari of Maiduguri metropolis. Those who are in the internally displaced person camps are not included in the target population. The respondents were residents with age between 18years and above. The instrument of this study was based on the socioeconomic and demographic profile of the respondents.

\section{Results and Discussion}

The objective of this study is to describe the socioeconomic and background profile of respondents using descriptive statistics.The respondents' background which includes; age distribution, gender, marital status, religious, inclination, the level of education, occupation, tenure, income, the number of family members, and length of stay as depicting in the table.1

Table 1. Background of the respondents $(N=383)$

\begin{tabular}{|l|c|c|c|c|}
\hline Variables & Frequency & Percent & M & SD \\
\hline Gender & & & & \\
\hline Male & 227 & 59.3 & & \\
\hline Female & 156 & 40.7 & & \\
\hline Age Group & & & $\mathbf{3 4 . 6 6}$ & $\mathbf{1 1 . 6 9}$ \\
\hline $18-35$ years & 237 & 61.9 & & \\
\hline $36-50$ years & 109 & 28.5 & & \\
\hline $51-65$ years & 29 & 7.6 & & \\
\hline$>65$ years & 8 & 2.1 & & \\
\hline Marital Status & & & & \\
\hline Single & 140 & 36.6 & & \\
\hline Married & 179 & 46.7 & & \\
\hline Divorced & 36 & 9.4 & & \\
\hline Widow & 28 & 7.3 & & \\
\hline Religion Inclination & & & & \\
\hline Islam & 244 & 63.7 & & \\
\hline Christian & 128 & 33.4 & & \\
\hline Others & 11 & 2.9 & & \\
\hline
\end{tabular}




\begin{tabular}{|l|c|c|c|c|}
\hline Level of Education & & & & \\
\hline Qur'anic Education & 42 & 11.0 & & \\
\hline Primary School & 21 & 5.5 & & \\
\hline Secondary School & 89 & 23.2 & & \\
\hline Tertiary Institutions & 231 & 60.3 & & \\
\hline Occupation & & & & \\
\hline Civil Servant & 127 & 33.2 & & \\
\hline Business & 111 & 29.0 & & \\
\hline Farmer & 50 & 13.1 & & \\
\hline Unemployed & 80 & 20.9 & & \\
\hline Artisan & 15 & 3.9 & & \\
\hline Tenure & & & & \\
\hline Owner occupier & 169 & 44.1 & & \\
\hline Rent & 214 & 55.9 & & \\
\hline $\begin{array}{l}\text { Number of Family } \\
\text { Members }\end{array}$ & & & $\mathbf{8 . 6 3}$ & $\mathbf{5 . 7 4}$ \\
\hline $1-5$ & 118 & 30.8 & & \\
\hline $6-10$ & 177 & 46.2 & & \\
\hline $11-15$ & 57 & 14.9 & & \\
\hline $16-20$ & 18 & 4.7 & & \\
\hline$>20$ & 13 & 3.4 & & \\
\hline Length of Stay & & & $\mathbf{1 5 . 0 6}$ & $\mathbf{1 1 . 3 6}$ \\
\hline $1-10$ years & 172 & 44.9 & & \\
\hline $11-20$ years & 124 & 32.4 & & \\
\hline $21-30$ years & 59 & 15.4 & & \\
\hline $31-40$ years & 15 & 3.9 & & \\
\hline $41-50$ years & 6 & 1.6 & & \\
\hline$>50$ years & 7 & 1.8 & & \\
\hline Income Distribution & & & $\mathbf{6 5 , 8 7 3}$ & $\mathbf{1 8 , 5 6 2}$ \\
\hline$<$ N10,000 & 16 & 4.2 & & \\
\hline N10,000 - N30,000 & 171 & 44.6 & & \\
\hline N30,001 - N70,000 & 103 & 26.9 & & \\
\hline N70,001 - N100,000 & 45 & 11.7 & & \\
\hline$>$ N100,000 & 48 & 12.5 & & \\
\hline & & & & \\
\hline
\end{tabular}

\section{Gender}

Among the total respondents of 383 , the descriptive analysis in Table.1 showed the gender distribution of male and female, in which male constitutes 59.3\% (227) and female were $40.7 \%$ (156). This indicated that males are the majority in the study area.

\section{Age Group}

The ages of the respondents ranged from $18-65$ and above years, in this regard, the descriptive analysis in Table 4.1 showed that, the age group of 18 - 35 years old were $61.9 \%$ (237), $36-50$ years old were $28.5 \%$ (109), $51-65$ years old were $7.6 \%$ (29) and 65 and above years old were $2.1 \%$ (8). Considering the Mean score of age $(M=34.66 \pm 11.69)$ which fall between $18-35$ years age group; this indicated that the respondents in that age category were the majority.

\section{Marital Status}

The respondents also defer in terms of their marital status. Out of 383 respondents, $46.7 \%$ (179) were married, followed by single $36.6 \%$ (140), divorced $9.4 \%$ (36) and $7.3 \%$ (28) were widows. Based on this result, the researcher deduced that, the respondents who are married were the slight majority. 


\section{Religion Inclination}

For religion inclination, out of 383 respondents majority of them i.e. $63.7 \%$ (244) were Muslims, followed by Christians $33.4 \%$ (128), and only $2.9 \%$ (11) from other religions.

\section{Level of education}

With regards to the respondents' level of education, those who attended Qur'anic school were $11.0 \%$ (42) respondents. Those who attended primary school were only 5.5\% (21), secondary school was $23.2 \%$ (89) and tertiary institutions were $60.3 \%$ (231). Based on the analysis, one can say the majority of the respondents have acquired tertiary education.

\section{Occupation}

For the respondents' occupation, those who are civil servant were $33.2 \%$ (127), business were $29.0 \%$ (111), farmers were $13.1 \%$ (50), unemployed were 20.9\% (80) and Artisan were 3.9\% (15). The analysis revealed that the civil servants were the slight majority, followed by business, then unemployed, then lastly, artisan.

\section{Tenure}

For the type of tenure, the owner-occupier were $44.1 \%$ (169) and rent were $55.9 \%$ (214). This means, rental occupants were the majority in the study area compared to owner occupants.

\section{Number of Family Members}

The result indicated differences in the family member's distribution. Out of 383, those who have between $1-5$ family members were $30.8 \%$ (118), 6 - 10 family members were $46.2 \%$ (177), 11 - 15 family members were $14.9 \%$ (57), 16 - 20 family members $4.7 \%$ (18) and respondents who have more than 20 family members were $3.4 \%$ (13). Based on the Mean of 8.63 and standard deviation of 5.74, the researcher deduced that, the majority of the respondents have between $6-10$ family members.

\section{Length of Stay}

For the length of stay in Maiduguri which refers to the duration of the respondents' years of living in Maiduguri, Table. 1 showed the distribution of years ranging from $1-50$ years and above. These years were further categorized into six groups. The first group was $1-10$ years length of stay which constitutes $44.9 \%$ (172); followed by the second group of $11-20$ years length of stay were $32.4 \%$ (124), third group of $21-30$ years length of stay were $15.4 \%$ (59), fourth group of $31-40$ years length of stay were $3.9 \%$ (15), fifth group of $41-50$ years length of stay were $1.6 \%$ (6) and finally, the sixth group of more than 50 years length of stay constitutes $1.8 \%$ (7). Considering the group frequency distribution of length of stay Maiduguri, the finding revealed that majority of the respondents fall within the first group of $1-10$ years length of stay in Maiduguri

\section{Income Distribution}

For the income distribution of the respondents, the result showed the distribution of income ranging from a minimum of less than $\$ 10,000$ to a maximum of more than $\$ 010,000$. These incomes were further categorized into five income classes. The first class is referred to very low-income class less than $\$ 10,000$ which constitutes $4.2 \%$ (16); followed by the low-income class $\$ 10,000-\$ 30,000$ were $44.6 \%$ (171), the middle-income class were $\$ 30,001$ - $\$ 70,000$ which constitutes $26.9 \%$ (103), the high-income class $\$ 70,001$ $\$ 100,000$ were $11.7 \%$ (45) and finally, the very high-income class which is more than $\$ 100,000$ constitutes $12.5 \%$ (48). Considering the group frequency distribution of income, the result showed that majority of the respondents fall within the low-income class $(\$ 10,000-\$ 30,000)$.

\section{CONCLUSION AND RECOMMENDATION}

The authors concluded that, based on the result of the analysis most residents are within the low-class group, the majority of the respondents are male, and on the average, the respondents are within the age bracket of 18 35.Most of them are married and the majority live in a rental apartment.In term of religion, predominantly the residents are Muslims.The researchers recommended that, socioeconomic and background profile of the residents in Maiduguri could provide relevant information on what the affected residents need mostly in terms of assistance that would improve their condition and relief them of the hardship been posed on them by the insurgency predicament 


\section{REFERENCES}

[1] Mallak, L. (1998). Putting Organizational Resilience to Work. Industrial Management (Norcross, Georgia), 40(6 NOV. /DEC.), 8-13.

[2] Timmerman, P. (1981). Vulnerability, Resilience and the Collapse of Society: A Review of Models and Possible Climatic Applications, Environmental Monograph 1. Institute for Environmental Studies, University Of Toronto, Toronto.

[3] Béland, D. (2005). The Political Construction of Collective Insecurity: From Moral Panic to Blame Avoidance and Organized Irresponsibility. Minda De Gunzburg Center for European Studies, Harvard University

[4] Goroshit, S. K. M., \& Eshel, Y. (2013). Demographic Variables as Antecedents of Israeli Community and National Resilience. Journal of Community Psychology, 41(5), 631-643.

[5] Anton, C. E., \& Lawrence, C. (2014). Home Is Where The Heart Is: The Effect Of Place Of Residence On Place Attachment And Community Participation. Journal of Environmental Psychology, 40, 451-461.

[6] Lewicka, M. (2005). Ways to Make People Active: The Role of Place Attachment, Cultural Capital, and Neighbourhood Ties. Journal of Environmental Psychology, 25, 381-395

[7] Lewicka, M. (2010). What Makes Neighbourhood Different From Home and City? Effects of Place Scale on Place Attachment. Journal of Environmental Psychology, 30, 35-51.

[8] Raymond, C., Brown, G., \& Weber, D. (2010). The Measurement of Place Attachment: Personal, Community, and Environmental Connections. Journal of Environmental Psychology, 30, 422-434.

[9] Stedman, R. C. (2006). Understanding Place Attachment among Second Home Owners. The American Behavioral Scientist, 50(2), 187-205.

[10] Lee, K. O. (2012). "Residential Relocation Decisions: The Role of Neighborhood Housing Characteristics." IRES Working Paper Series

[11] Anacio, D. B., Hilvano, N. F., Burias, I. C., Pine, C., Nelson, G. L. M., \& Ancog, R. C. (2016). Dwelling structures in a flood-prone area in the Philippines: Sense of place and its functions for mitigating flood experiences. International Journal of Disaster Risk Reduction, 15, 108-115.

[12] Omagwa, J.O. \& Aduda, J.O (2015). The Influence of Demographics on Owner-Occupied Housing Decisions: A Case of Apartment Households in Nairobi County, Kenya. Business \& Entrepreneurship Journal 4(1) 11-26.

[13] Bonanno, G. A., Galea, S., Bucciarelli, A., \& Vlahov, D. (2007). What predicts Psychological Resilience after Disaster? The Role of Demographics, Resources, and Life Stress. Journal of Consulting and Clinical Psychology, 75(5), 671.

[14] Neuman, W. L, (2006) Social Research Methods; Qualitative and Quantitative Approaches. $\left(6^{\text {th }}\right.$ Edition). Boston Allyn and Beacon. 